Ә OPEN ACCESS

\title{
Maqasid Al-Syariah dan Reformulasi ljtihad Sebagai Sumber Hukum Islam
}

\author{
A.Gazali \\ * Manajemen Dakwah, Fakultas Dakwah dan Ilmu Komunikasi, Banjarmasin, Indonesia \\ *Email; ahmadgazalihb@gmail.com
}

\section{ABSTRACT}

Islamic law in the study of usul al-figh places Alquran, the Sunnah of Rasul, ijma and qiyas as a standard source. But in the application and development found a variety of sources in the concept and formulation. This diversity is not only due to the factor of the existence of figh schools, but it is also a necessity of the wrong manifestation of the al-Shari'at maqasid.

KEYWORDS As-Syari'ah; Al-maqasid al-syari'at; al-maslahah; fiqh; the source of Islamic law

\begin{abstract}
ABSTRAK
Hukum Islam dalam wacana kajian usul al-fiqh menempatkan Alquran, sunnah rasul, ijma dan qiyas sebagai sumber standar. Namun dalam aplikasi dan perkembangannya ditemukan aneka ragam sumber dalam konsep maupun formulasinya. Keragaman tersebut bukan hanya dipengaruhi oleh faktor adanya mazhab-mazhab fikih, tetapi juga merupakan suatu keniscayaan dari perwujudan salah maqasid al-Syari'at.Guna merespon keragaman itulah diperlukan sumber hukum "eksternal" sebagai metodologi alternative dalam menghadapi perkembangan global.
\end{abstract}

KATA KUNCI As-Syari'ah; Al-maqasid al-syari'at; al-maslahah; fiqh; sumber hukum Islam

\section{Pendahuluan}

Hukum Islam merupakan suatu fenomena yang berkaitan erat sekali dengan perkembangan yang terjadi pada masa yang silam.(AA. Fyzee, 1955:1) menyatakan bahwa hukum Islam: adalah hasil suatu proses perkembangan yang terus menerus selama tersiarnya Islam dalam masa empat belas abad".

Tahap permulaan dari perkembangan hokum islam adalah di zaman Rasul SAW. Dan khulafa ar-Rasyidin suatu fase dimana hokum Islam dilaksanakan 
dalam rangka mengawali terbinanya suatu "Islamic Community" sebagaimana yang dihendaki oleh Allah SWT.Dalam Alquran secara benar.

Perkembangan politik pada masa perkembangan sesudahnya telah membuka perdebatan wacana intelektual tentang prinsip-prinsip kebenaran hukum Islam. Walaupun demikian masih ada pendapat yang mengatakan dan menanggap bahwa masa itu sebenarnya belum ada apa yang dinamakan "hokum Islam".

Menurut para ahli, hukum Islam itu baru lahir menjelang akhir abad pertama atau awal abad kedua hijrah bersamaan dengan munculnya aliran atau mazhab fiqh dalam dunia Islam. Pendapat yang demikian muncul karena ada yang memisahkan antara syariat (hukum-hukum yang langsung ada dalam Alquran) dengan hukum figh, dan melihat kaidah-kaidah fiqh adalah ditemukan dalam karya-karya fuqaha masa silam.

Adanya pandangan yang memisahkan antara syariat dengan hukum figh, telah melahirkan pandangan yang keliru tentang hukum Islam. Salah satu pandangan yang menyesatkan dikemukakan oleh Snouck Hurgronje yang menyatakan bahwa: "... bukannya Alquran yang memberikan pengertian tantang Islam kepada kita, akan tetapi kitab-kitab hukum (figh) dan teologi yang ada semenjak abad III H.(H.M, Rasyidi: 1968:15) Pandangan seperti ini banyak mempengaruhi intelektual muslim yang mempelajari hukum Islam dari sumber Barat.

Fase kedua dari perkembangan hukum Islam merupakan studi intensif tentang fiqh dengan lahirnya para fuqaha dan mujahid yang telah memperkembangkan prinsip-prinsip hukum yang termuat dalam Alquran dan sunnah melalui ijtihad, sehingga terbentuklah aliran pemikiran hukum Islam yang mengelompokkan diri dalam berbagai mazhab fiqh maupun secara individual yang pemikirannya banyak mempengaruhi perbincangan dan diskursus tentang hukum Islam dan menyentuh kerangka filosofis hukum seperti hakikat dan tujuan hukum (Islam). Tulisan ini bermaksud mengetangahkan kedua hal tersebut, yakni Maqasid al-Syariat dan elaborasi pemahaman ijtihad, dan penulis berharap bahasan ini dapat membuka lebih luas perdebatan tentang dinamika hukum Islam. 


\section{Pembahasan}

\section{Syariat dan Maqasid Al-Syariat}

1. Hakikat Syariat

Para fuqaha dan terutama Al-Syatibiy dalam Al-Muwafaqat fi Usulil Ahkam menengahkan konsep bahwa pada hakekatnya syariat itu ajaran hukum yang diuraikan dengan wahyu. Dalam tataran epistimologi istilah akal dan hawa dipakai sebagai istilah yang kontras dengan syariat. Baginya bahwa:

a. Hukum itu tidak boleh didasarkan atas kesenangan pribadi,

b. Nilai-nilai yang mendasari syariat tidak ditentukan oleh akal manusia,

c. Syariat bersifat absolut dan universal

Dengan penelitian ini istilah lain yang digunakan terhadap hukum Islam adalah fiqh yang di sebut Al-Syatibiy sebagai ekspresi dari kehendak kreatif Tuhan, sedangkan syariat merupukan ekspresi aspek legislatif Tuhan. Karena itu, keduanya tidak dapat dipisahkan.

Dengan demikian, hukum Islam (figh) digunakan untuk arti harfiah dan arti pokok dari makna teknis kehendak syariat atau pemahaman kontekstual terhadap syariat. Secara ontology tidak ada tempat bagi perbedaan pendapat dalam syariat dan prinsip "mura'at al khilaf" bukan pada syariat tetapi pada figh. Oleh sebeb itu, semua ketentuan hukum berasal dari satu akar yaitu (Allah dan Rasul).

Kerangka pemikiran ini bertolak dari hal-hal yang secara keseluruhan ayat Alquran menekankan konstruksi kestauan original syariat. Nuansa perbedaan dalam nas lebih diartikan sebagai pemberian tempat bagi masalah nasakh (teori alternatif bukan teori penghapusan). Ini akan berarti mengimplikasikan posisi dari suatu kewajibann yang tidak mungkin dilaksanakan pada masanya kepada pilihan alternative dari kewajiban yang lain. Karena memerintahkan seseorang untuk melaksanakan dua perintah yang kontrakdiksi dalam waktu yang bersamaan berarti memposisikannya pada kewajiban yang tidak mungkin ditunaikan.

Akan menjadi suatu yang tidak mungkin dipertahankan bahwa kedua perintah yang dianggap bertentangan secara simultan dilaksanakan, dikehendaki oleh pembuat hukum karena berarti yang satu akan "menegaskan yang lain". Syariat tidak mempunyai jenjang normal, ia hanya mempunyai kesastuan asal muasal syariat yakni al Hakim (Allah SWT). 
Karenanya ijtihad diperlukan sebagai metode (legal reasoning) dalam kerangka penerapan syariat kepada hal-hal rinci dari aspek kehidupan manusia.

\section{Maqasid al-Syariat}

Seluruh aturan hukum Islam pada prinsipnya didedikasikan untuk mewujudkan tujuan (muqasid) yang dikehendaki oleh pembuat hukum (Al Hakim) yaitu manusia serta terpeliharanya kesejahteraan (maslahah) agama, jiwa, akal, keturunan, dan harta.

Apabila suatu ketentuan hukum sudah tidak lagi sesuai dan tidak mampu mewujudkan tujuan tersebut, maka ia dipandang tidak efektif dan karena itu perlu ijtihad untuk mereformasi bentuk baru dari hukum yang lebih dapat menjamin terwujudnya tujuan syariat yakni "maslahah". Kemaslahaian umat manusia. Asy-Syatiby menyebutkan maslahah sebagai Maqasid alSyariat dalam arti "kebaikan dan kesejahteraan".

Al Gazaly (w. 505 H.) menjelaskan bahwa maslahah sebagai maqasid alSyariat secra etimologi berarti mendatangkan kemanfaatan dan menghindari hal-hal yang membawa kerugian (mudharat) yang dalam makna lain ia disebutkan dengan arti mempertahankan tujuan-tujuan yang dikehendaki oleh syariat (law giver), yakni memelihara agama, jiwa, akal, keturunan, dan harta.(Gazali:1937:286)

Al Tafi (tokoh Mazhab Hambali) menjelaskan bahwa: maslahah sebagai maqasid al-syariah adalah menjadikan tujuan yang dikehendaki oleh pmbuat syari'at, karena menjadi hak-Nya dan tujuan yang dikehendaki-Nya untuk kesejahteraan dan keteraturan kehidupan makhluk-Nya.(Husein Hamid Hasan:1971:9)

Bila al-maslahah dimaknai dengan kemanfaatan, kebaikan dan kesejahteraan umat, sesungguhnya penelitian ini menyentuh aspek teologis dengan premis bahwa Tuhan (Al Hakim) melembagakan hukum-hukum demi kebaikan dan kesejahteraan kehidupan makhluk-Nya, disinilah ruang gerak ijtihat sangat dibutuhkan memformulasi sumber hukum Islam.

Premis ini menunjukkan bahwa upaya mewujudkan Maqasid al-Syari'at tersebut senantiasa berkaitan dengan etika (moralitas).Karena persoalan 
kebaikan dan kesejahteraan tidak semata-mata persoalan material, tetapi lebih kepada aspek motivasi dan jiwa untuk menciptakan al-maslahah.

Hanya kemudian bila kedua aspek tersebut terkait dengan Maqasid alSyari'at, akan muncul problematika relativitas "kebaikan dn kesejahteraan". Hubungan kebaikan dan kesejahteraan dengan beban dan kesenangan jiwa manusia. Oleh sebab itu Implikasi determinan teologis dan dilemma relativitas kebaikan dan kesejahteraan ini akan menyeret seseorang untuk mendiskusikannya ke dalam dua level, pertama wacana tentang tujuan hukum dan kedua wacana tentang subjek hukum.

Dalam syariat norma etika (moralitas) terintegrasi kedalam norma hukum oleh nilai al-maslahah. Dengan bingkai norma inilah penerapan hukum dilaksanakan yang akan bermuara pada kasih sayang. Kasih sayang inilah yang menghilangkan "sifat pembalasan" dalam fungsi hukum dan membedakannya dengan system hukum lain. Kasih sayang adalah cahaya petunjuk, yang berfungsi membimbing manusia lemah berjalan di jalan yang lurus.

Ibnu al Qayyim mengulas Maqasid al-Syaria'at ini dengan mengatakan: "Syariat dasarnya adalah hikmah dan kemaslahatan manusia dalam kehidupan dunia dan ukhrawi. Di dalamnya ada unsur keadilan, kerohanian, dan hikmah seluruhnya. Setiap masalah yang keluar menyimpang keadilan adalah keonaran dan kekacauan, menyimpang dari rahmat kepada sebalikanya, menyimpang dari kemalahatan kepada kerusakan dan menyimpang dari hikmah kepada kekejian, semua itu bukan dari syari'at. Walau dengan tafsiran bagaimanapun syari'at adalah keadilan Allah kepada hamba-Nya, rahmat Allah diantara makhluk-Nya, dalam rangka menjamin hidup dan kebahagiaan, obat dan kewarasan, cahaya dan perlindungan dengan syari'at, dan setiap kekurangan dalam wujud, sebabnya tidak lain karena melalaikan syari'at. Maka syari'at yang dibawa Rasul SAW, itulah tiang alam ini, dan pangkal dasarnya kebahagiaan serta keselamatan di dunia dan di akherat.(Ibnu al-Qoyyim)

\section{Sumber dan Perkembangan Hukum Islam}


Tradisi kajian hukum Islam selalu beranjak dari instrument tekstual dan melalui penelusuran "perkiraan" normative. Karena itu persoalan yang muncul ditengah realita kehidupan umat dikontrol ke dalam bingkai makna harfiah dari nas (Alquran dan hadist) yang seringkali berakibat terjadinya distorsi pemaknaan nas menjadi sempit dan terbelenggu dalam penafsiran yang otoritatif. Kelemahan ini harus disadari, karena sumber hukum yang diyakini dengan komitmen keagamaan hanya Alquran, sunnah, ijma dan qiyas. (Subhi Mahmasani, 1981:101)

Dua yang terakhir itu biasannya diterjemahkan dengan consensus yang ketat melalui kesepakatan orang-orang yang punya otoritas dalam bidangnya, dan penalaran melalui analogi. Walaupun ijma' dan qiyas tidak secara jelas disebutkan dalam Alquran dan sunnah sebagai sumber syari'at, namun perkembangkan kedua sumber tersebut sebagai sumber syari'at adalah produk metode yang disepakati para mujtahid yakni ijtihad sebagai akibat perkembangan hukum Islam pada abad II dan III H.(Abdullah A. An-Na'im, 1994:38)

Perluasan daerah Islam berimbas dengan terbukanya wacana hukum Islam dan hukum Islam mau tidak mau harus bertemu dengan berbagai system hukum yang telah berkembang selama itu seperti hukum Romawi dan peradaban Barat lainnya.

Dalam fase perkembangan ini banyak ditulis tentang interprestasi hukum yang tetap dipergunakan sampai kini. Hukum Islam meskipun bersumber pada Alquran dan sunnah rasul, ternyata menampakkan aneka ragam dalam konsep maupun formulasi. Setiap fuqaha memiliki metode yang tidak sama dalam memahami setiap pernyataan Alquran maupun sunnah yang tercermin dalam konfigurasi aliran atau mazhab fiqh.

Perkembangan mazhab ternyata menimbulkan pemikiran yang bersifat ekslusif tentang hukum Islam.Kebanyakan para ahli hanya mengikuti saja kepada hasil-hasil pemikirannya pendahuluan yang melahirkan sikap taklid yang membekukan dinamika hukum Islam pada abad pertengahan. Masa kebekuan dalam perkembangan pemikiran hukum Islam mulai mencair kembali semenjak munculnya gerakan pembaharu (tajdid) yang dipelopori oleh gerakan Jamaluddin al Afghaniy (1830-1837), Muhammad Abduh (1845-1899), dan Sayyid 
Rida (1703-1787). Pemikiran mereka bukanlah suatu pemikiran yang muncul secara spontan akan tetapi akar-akarnya sudah diletakkan oleh Ibnu Taimiyah (1263-1328), Ibnu al-Qayyim (1292-1350) dan Ibnu Abdul Wahab (1703-1787).

Pada dasarnya mereka bertujuan menegakkan "kemurnian" hukum Islam yakni prinsip-prinsip yan tetap didasarkan pada Alquran dan Hadist dengan melakukan pengembangan sendiri melalui ijtiad serta menolak prinsip taklid dan karenanya juga melepaskan diri dari keterkaitan dengan kitab-kitab hukum mazhab yang tertulis pada masa lampau.

Perkembangan pemikiran semacam ini sangat membantu pertumbuhan hukum Islam ketika berhadapan dengan komitmen umat Islam yang beragam dan dunia modern yang berkembang pesat.

Realitas yang dihadapi umat Islam menyadarkan dan harus dipahami bahwa nash atau sumber hukum Islam tidak memberikan formulasi hukum yang mempunyai aktualisasi yang sepadan dengan seluruh dan keanekaragaman kebutuhan riil hukum. Karenanya pula disamping kaidah-kaidah "qat'iyah" yang memiliki daya ikat yang kuat, masih ada peluang analisis dan elaborasi maknawi terhadap kaidah-kaidah "zanniyah".Peluang semacam ini telah diberikan oleh pengalaman sejarah bahwa banyak sekali peranan manusia dalam pemenuhan kebutuhan hukum masyarakat Islam, yang disebut dengan ijtihad.

Oleh karena itu, kajian hukum Islam masa kini harus menggunakan permasalahan hukum yang hidup dalam masyarakat (dalam berbagai sektor) sebagai penuntut kajian tekstual dan kajian ini cenderung mempermudah proses aktualisasinya. Berbeda dengan kajian tradisional, kajian ini menawarkan pendekatan tematis nash (Alquran dan Hadits) ke dalam persoalan hukum yang hidup dalam masyarakat.(Abdul Gani Abdullah, 1997:14)

Kajian tematis dalam hukum juga akan menempatkan hukum Islam dalam posisi yang strategis dan signifikan dalam memecahkan persoalanpersoalan yang timbul dalam masyarakat modern. Karena kajian tematis cenderung terkait dengan konsentrasi kajian syariat dengan aspek sosial, politik, ekonomi, reproduksi manusia, tranplantasi organ tubuh, kawin beda agama, asuransi, jasa dan investasi.

Konfigurasi hukum Islam dengan kajian tematisyang demikian sekaligus memformulasikan sember hukum; Alquran, as sunnah, dan ijtihad (ijma' dan 
qiyas) sebagai sumber hukum internal. Suatu keniscayaan menjadikan hal ihwal kemanusiaan, adat dan kebudayaan, system hukum internasional, teori-teori ilmu pengetahuan modern sebagai sumber eksternal melalui metodologi Islam alternatif yang dapat mencapai keseimbangan antara modernitas dan keabsahan Islam.

Ibnu Khaldun telah membuka diskursus seperti ini dengan mengatakan: "Hal ihwal umat manusia, adat kebiasaan dan peradabannya tidaklah pada satu gerak dan khittah yang tetap, melainkan berubah dan berbeda-beda sesuai dengan perubahan zaman dan keadaan. Adalah bagaimana halnya manusia itu sendiri, waktu dan tempat, maka keadaan itu terjadi pula pada dunia dan Negara.Sungguh bahwa Sunnatullah berlaku pada hamba-hamba-Nya.

Diskursus ini mengajarkan bahwa formulasi hukum Islam (fiqh) tidak bersifat tetap dan abadi.la merubah sesuai dengan tuntutan yang timbul dalam kondisi tempat dan waktu tertentu. Ajaran yang seperti ini dikalangan fuqaha belum bisa diterima sebagai aksioma dan masih dipertanyakan lagi kebenarannya. Meskipun demikian, Ibnu al-Qoyyim (w.751 H) pernah berkata: "Fatwa berubah dan berbeda-beda menurut perubahan waktu, tempat, keadaan dan kebiasaan".(Sobhi Mahmasani)

Oleh sebab itu, setelah satu postulat, yang mengawali pembahasan wacana hukum Islam masa kini adalah adanya asas perubahan hukum, dan asas perubahan ini merupakan perwujudan dari salah satu Maqasid al-Syari'at, agar hakekat dan prinsip syariat tidak mengalami goncangan ketik berhadapan dengan perkembangan masyarakat modern. Aktualisasi atas asas-asas inilah yang menempatkan ijtihad dalam posisi yang sentral strategis dalam upaya mencapai maqasid al-syaria'at, al-maslahah.

\section{Upaya Mencapai Mașaḥah melalui ljtihăd}

ljtihăd dalam arti bahasa telah menunjukkan makna kerja keras atau bersungguh-sungguh. Kalimat ini menunjukkan kepada pekerjaan yang dilakukan lebih dari biasa dan memerlukan ketekunan, meskipun oleh sebagian orang kurang disenangi. (Musa Towana,1972)

Menurut Sobhi Mahmasani secara istilah ljtihădadalah meluangkan kesempatan dan usaha untuk mengetahui ketentuan-ketentuan hukum dari dalil 
syariat. Bila ljtihădsecara harfiah-normatif berarti usaha keras dan gigih, secara teknis berarti penggunaan penalaran makna hukum secara independen untuk memberikan jawaban atas suatu masalah ketika Alquran dan sunah "diam" tak memberikan jawaban.

Oleh sebab itu, ketika ljtihad diizinkan oleh Rasul Allah SAW, kepada Mu'azd ibn Jabal, fenomena itu bukan saja menunjukkan adanya kemungkinan suatu persoalan tidak dijelaskan secara gamblang oleh Alquran dan sunah.Tetapi juga itu berarti bahwa ljtihădadalah sumber hukum Islam.

Dalam konteks ini jelaslah bahwa ljtihădadalah konsep yang mendasar dan sangat efektif dalam usaha pembentukan hukum Islam dan upaya pencapaian Maqășid al-Syari ’at.

Umar ibn khattab ra. Tidak memberikan bagian muallaf dari zakat, melarang penjualan "ummahătu al-awlăd", menganggap talak 3 yang diucapkan sekaligus dalam satu majelis tetap sah (jatuh talak 3), ljtihăd-ljtihăd 'Umar tersebut menunjukkan bahwa untuk mencapai maqășidu al- syari at, al-mașlahah sangat hubungan dengan penggunaan ijtihad baik sebagai sumber hukum mempunyai sebagai metode (istinbăt aḥkăm). Hal inilah yang melatar belakangi munculnya konsep al-mașlaḥah bukan konsep-normatif, tetapi suatu aplikasi dan implikasi bahwa tujuan hukum Islam dapat dirasakan secara realitis dalam kehidupan manusia.Hakiki Islam adalah rahmat untuk seluruh alam semesta.

Untuk mencapai tujuan tersebut diperlukan elaborasi pemaknaan ljtihăd, pertama perlunya dikembangkan penafsiran (ljtihăd) sosial-struktural lebih daripada sekedar ljtihădindividual ketika kita memahami ketentuanketentuan nash Al-quran. Kedua mengubah cara berpikir yang subjektifbertujuan untuk "pembersihan " atau"pensucian" harta dan jiwa. secara objektif tujuan zakat adalah harus tercapainya kesejahteraan dan kebaikan (Mașlahah) kehidupan sosial. Ketiga, mengubah cara pandang dari Islam normatif (halalharam atau hitam-putih) menjadi teoris.

Dengan pendekatan teoritis kita dapat memahami konsep tentang kaum dan miskin pada konteks yang lebih riil, aktual sesuai dengan kondisi sosial, ekonomi, kultural maupun politik.Kalau kita dapat mereformulasikan hukum secara teoritis akan lebih banyak kemaslahatan yang dapat mengayomi kehidupan umat. Keempat, mengubah pemahaman ahistoris menjadi 
historis.Cerita yang termuat dalam Alquran merupakan isyarat pendekatan historis ketika kita memahami makna yang mungkin dikehendaki oleh Alquran. Kelima, merumuskan formulasi-formulasi wahyu yang versifat spesifik dan empiris. Pernyataan tentang larangan kekayaan tidak boleh beredar hanya di kalangan kaum kaya misalnya adalah persyaratan yang general. Dalam realitas empiris saat ini dapat saja diartikan dengan formulasi larangan monopoli dan oligopoli dalam aspek ekonomi.(Kuntowijoyo, 1991:283)

Aplikasi ljtihăd seharusnya tidak lagi berada dalam kerangka prinsipprinsip mazhab fiqh yang membatasi hanya pada masalah-masalah yang belum ada dalam teks Alquran dan sunnah dan aspek-aspek furuiyah, tetapi lebih kepada pemecahan yang fundamental dari hukum publik syari ah dan untuk kepentingan umat manusia guna mencapai esensi tujuan hukum Islam. (Fazlur Rahman, 1965:180)

Persepsi seperti inilah yang mungkin mendasari ljtihăd Umar ibn Khattab ra. Dengan demikian ljtihăddapat dimaknai sebagai metode penetapan hukum Islam yang tidak berdasarkan rash (teks).Tetapi berdasarkan maqășid al- Syari at; almaslahah masyarakat (umat) atau petimbangan evolusi zaman dan perubahan tempat.(M. Faruq An-Nabban:1981:117)

\section{Simpulan}

Faktor kesadaran hukum Islam di kalangan umat sangat penting dalam kehidupan dan perkembangan hukum, dan akan ikut menentukan apakah hukum Islam dapat terlaksana, baik secara formal maupun substansial, dikalangan umat atau tidak. Kesadaran itu akan muncul bila hukum Islam cakrawala yang luas diperlukan. Filsafat hukum Islam memegang kunci pemecahan masalah-masalah hukum Islam yang akan diterapkan dalam masyarakat.

Hukum Islam tidak akan muncul tanpa diperjuangkan, tetapi setiap perjuangan memerlukan seni, jika tiidak mewujudkan formalitas sebuah hukum Islam, paling tidak materi dan substansi Islam dapat terlaksana. Islam adalah agama rahmat bagi alam semesta.Hukum Islampun harus mencerminkan kasih sayang Allah SWT.kepada alam dan seisinya. Oleh karena itu, penyampaian hukum Islam haruslah menggunakan cara yang ramah tamah. 


\section{Referensi}

Abdullah, Abdul Gani. 1997. "Hukum Islam dalam Sistem Masyarakat Indonesia" dalam mimbar hukum. Jakarta: DITBINBAPERA

Fyzee, AA. 1955. Outline of Muhammadan Law. London: Oxford University Press

Gazali, al-. 1937. al-mustasyfă min 'Ilmi al-Usul. al-Matba'ah al-Amiriyah: Mesir

Hasan, Husein Hamid. 1971. Nazariyat al-Maslahah fi al-Figh al-Islamiy. Mesir: Dar al-Nahdah al-'Arabiyah

Khaldun, Ibnu. Al-Muqaddimah, Al-Baiyah. Mesir, t.th.

Kuntowijoyo. 1991. Paradigma Islam Interprestasi Untuk Aksi. Bandung: Mizan

Mahmasani, Subhi. 1981. Falsafah al-Tasyri' fi al-Islamiy, Dar al-Kasyafi li al-Nasyri, Mesir, t.th, terj. Al-Maarif, Bandung

Naim, Abdullah Ahmed An-. 1994. Toward an Islamic Reformation, Yogyakarta: Terj.Pustaka Pelajar

Nabban, Muh. Faruq Al. 1981. Al-Madkhal li al-Tasyri' al-Islam, Dar al-Qalam, Beirut Qoyyim, Ibnu al-. I'lamu al-Muwaqi'in 'an Rabbi al-'alamiin, Dar al-Fikr. Beirut, IV.

Rahman, Fazlur. 1965. Islamic Methodology in History, Central Institute os Islamic Research, Karachi

Rasyidi, H.M. 1968. Islam dan Indonesia di Zaman Modern. Jakarta: Bulan Bintang Syatibiy, Asy-. Al-Muwafaqatu fi al-Usuli al-Ahkam. Dar al-Fikr. Kairo, t.th.

Musa Towana. 1972. Ijtihad: Maza Hayatina llahi fi Haza al'Asr, Dar al-Kutub alHadisah, Kairo, Mesir 